\title{
Effects of dietary carbohydrases on productive performance and immune responses of lactating sows and their piglets
}

\author{
Jeong Jae Lee ${ }^{1 \#}$, Seong Ho Choi ${ }^{2 \#}$, Jin Ho Cho ${ }^{2 \#}$, Jeehwan Choe ${ }^{3 \#}$, Joowon Kang ${ }^{1}$, Soyun Kim", \\ Sangwoo Park ${ }^{1}$, Hyunjin Kyoung ${ }^{1}$, Dongoh Seo ${ }^{1}$, Jee-Yeon $\mathrm{Cho}^{4}$, Il-Hun Park ${ }^{4}$, Sangnam Oh ${ }^{5}$, \\ Hyeun Bum $\mathrm{Kim}^{6^{*}}$ and Minho Song ${ }^{1^{*}}$ \\ ${ }^{1}$ Division of Animal and Dairy Science, Chungnam National University, Daejeon 34134, Korea \\ ${ }^{2}$ Division of Food and Animal Science, Chungbuk National University, Cheongju 28644, Korea \\ ${ }^{3}$ Department of Beef Science, Korea National College of Agriculture and Fisheries, Jeonju 54874, Korea \\ ${ }^{4}$ DSM Nutrition Korea Ltd., Seoul 06675, Korea \\ ${ }^{5}$ Department of Functional Food and Biotechnology, Jeonju University, Jeonju 55069, Korea \\ ${ }^{6}$ Department of Animal Resources Science, Dankook University, Cheonan 31116, Korea
}

\section{Abstract}

This study was conducted to evaluate effects of dietary multi-carbohydrases (MCS) in a lactating sow diet on productive performance and immune responses of sows and their piglets. A total of 12 sows ( $218.37 \pm 5.5 \mathrm{~kg} \mathrm{BW} ; 2$ parity) were randomly assigned to 2 dietary treatments: a diet based on corn-soybean meal (CON) and CON with $0.01 \%$ MCS. The MCS contained xylanase (2,700 units/g), $\beta$-glucanase (700 units/g), and cellulase (800 units/g). Sows were fed the dietary treatments for 28 days (weaning) after farrowing. Blood samples were collected from sows on $\mathrm{d} 0,3$, and 7 after farrowing and randomly selected 2 nursing piglets in each sow on $\mathrm{d} 3,7$, and 14 after birth. Measurements were productive performance of sows, frequency of diarrhea of piglets, and immune responses of sows and their piglets. Sows fed MCS had lower $(p<0.05)$ their body weight change than those fed CON. Piglets from sows fed MCS had higher $(p<0.05)$ average weight gain and body weight at weaning day and lower $(p<0.10)$ frequency of diarrhea than those from sows fed CON. Sows fed MCS had lower number of white blood cells (WBC) on $\mathrm{d} 3(p<0.05)$ and TGF- $\beta 1$ on $\mathrm{d} 7(p<0.10)$ during lactation than those fed CON. Similarly, piglets from sows fed MCS had also lower $(p<0.05)$ number of WBC on $d 3$ and $d 7$ and TGF- $\beta 1$ and C-reactive protein on $\mathrm{d} 7$ during lactation than those from sows fed CON. In addition, piglets from sows fed MCS had higher $(p<0.10)$ immunoglobulin $\mathrm{G}$ and $\mathrm{M}$ on $\mathrm{d} 7$ during lactation those from sows fed CON. In conclusion, addition of dietary MCS in the lactating sow diet based on corn and soybean meal improved productive performance of sows and their litters and modulated their immune responses.

Keywords: Carbohydrase, Immune responses, Lactating sows and their litter, Productive performance

Received: Oct 11, 2019 Revised: Nov 8, 2019 Accepted: Nov 8, 2019

"These authors contributed equally to this work.

"Corresponding author: Minho Song, Division of Animal and Dairy Science, Chungnam National University, Daejeon 34134, Korea.

Tel: +82-42-821-5776, E-mail: mhsong@cnu.ac.kr

Hyeunbum Kim, Department of Animal Resources Science, Dankook University, Cheonan 31116, Korea.

Tel: +82-41-550-3653, E-mail: hbkim@dankook.ac.kr

This is an Open Access article distributed under the terms of the Creative Commons Attribution Non-Commercial License (http://creativecommons.org/licenses/by$\mathrm{nc} / 4.0 /$ ) which permits unrestricted non-commercial use, distribution, and reproduction in any medium, provided the original work is properly cited.

Copyright (c) 2019 Korean Society of Animal Science and Technology. 
ing a real-time ultrasound scanner (Anyscan BF, SongKang GLC Co., Seongnam, Korea) at farrowing and weaning. The presence of diarrhea from each piglet was checked visually each day for lactation and recorded with two scales: the presence of diarrhea or not. Frequency of diarrhea was calculated by counting piglet days with the presence of diarrhea.

Blood samples were collected from a jugular vein of each sow on $\mathrm{d} 0,3$, and 7 of lactation and randomly selected two piglets (1 barrow and 1 gilt) per sow on d 3, 7, and 14 of lactation using EDTA tubes (Becton Dickinson Vacutainer Systems, Franklin Lakes, NJ, USA) with anticoagulant and serum tubes.

Measurements of white blood cells and serum cytokines, acute phase protein, cortisol, and Immunoglobulin G, M, and $A$

The number of white blood cells (WBC) was analyzed using an automated hematology analyzer calibrated for porcine blood (scil Vet abc hematology analyzer, scil animal care company, F-67120 Altorf, France). The serum tumor necrosis factor- $\alpha$ (TNF- $\alpha$; R\&D Systems, Inc., Minneapolis, MN, USA), transforming growth factor- $\beta 1$ (TGF- $\beta 1$; R\&D Systems, Inc., Minneapolis, MN, USA), C-reactive protein (CRP; Abnova Corp., Taipei City,
Taiwan), cortisol (Cusabio, Wuhan, China), and immunoglobulin G, M, and A (IgG, IgM, and IgA; Abnova Corp., Taipei City, Taiwan) were measured using porcine ELISA kits and following the procedure of manufacturer.

\section{Statistical analyses}

Data were analyzed using the PROC GLM procedure of SAS (SAS Inst. Inc., Carry, NC, USA) in a completely randomized design. The experimental unit were sow and litter. The statistical model for productive performance and immune responses of sow and litter included effects of dietary treatment and parity as a covariate. The $\chi^{2}$ test was used for the frequency of diarrhea. Results were presented as means and standard error of the mean. Statistical significance and tendency were considered at $p<0.05$ and $0.05 \leq p$ $<0.10$, respectively.

\section{Results and Discussion}

Sows fed MCS had less $(p<0.05)$ body weight loss during lactation than those fed $\mathrm{CON}$, but there were no differences on other productive performances of lactating sows between $\mathrm{CON}$ and MCS (Table 2). Regarding longevity of sows, sows need to

Table 2. Productive performance of lactating sows fed dietary treatments

\begin{tabular}{|c|c|c|c|c|}
\hline \multirow{2}{*}{ Item } & \multicolumn{2}{|c|}{ Treatments } & \multirow{2}{*}{ SEM } & \multirow{2}{*}{$p$-value } \\
\hline & CON & MCS & & \\
\hline Sows $(n)$ & 6 & 6 & - & - \\
\hline Parity & 2.1 & 2.1 & 0.041 & 0.283 \\
\hline Weaning days (d) & 29.00 & 28.33 & 0.767 & 0.553 \\
\hline Feed intake (kg) & 183.28 & 182.45 & 2.345 & 0.785 \\
\hline ADFI (kg) & 6.32 & 6.44 & 0.119 & 0.491 \\
\hline Initial BW (kg) & 254.92 & 248.13 & 14.964 & 0.755 \\
\hline Final BW (kg) & 239.45 & 240.28 & 14.583 & 0.969 \\
\hline BW change $(\mathrm{kg})$ & -15.47 & -7.85 & 1.525 & $<0.05$ \\
\hline Initial backfat depth (mm) & 20.83 & 21.26 & 0.379 & 0.446 \\
\hline Final backfat depth (mm) & 18.10 & 18.66 & 0.395 & 0.340 \\
\hline Backfat depth change (mm) & 2.73 & 2.60 & 0.295 & 0.753 \\
\hline Born alive piglets ( $\mathrm{n}$ ) & 10.53 & 10.81 & 1.051 & 0.850 \\
\hline Died piglets (n) & 0.67 & 0.87 & 0.380 & 0.592 \\
\hline Weaned piglets (n) & 9.83 & 9.96 & 1.046 & 0.761 \\
\hline BW of born piglets $(\mathrm{kg})$ & 1.61 & 1.61 & 0.08 & 0.970 \\
\hline BW of weaned piglets $(\mathrm{kg})$ & 6.93 & 7.55 & 0.175 & $<0.05$ \\
\hline Average BW gain of piglets $(\mathrm{g} / \mathrm{d})$ & 183.49 & 210.91 & 8.100 & $<0.05$ \\
\hline Frequency of diarrhea of piglets $(\%)^{1)}$ & 9.75 & 8.63 & - & $<0.10$ \\
\hline
\end{tabular}

Values are presented as the least squares mean of 6 replicates.

${ }^{1)}$ Frequency of diarrhea of nursery pigs $=$ (number of diarrhea/number of nursery pigs) $\times 100$. Data was analyzed by the $\chi^{2}$ test.

CON, control diet based on corn and soybean meal; MCS, multi-carbohydrase diet; SEM, standard error of means; ADFI, average daily feed intake; BW, body weight. 
recover their feed intake during lactation as soon as possible after farrowing because lactating sows use more their energy to produce milk than to recover and/or maintain their body condition for next reproduction $[17,18]$. Due to the energy use of lactating sows, they generally lose their body weight and backfat depth $[19,20]$. However, the present study showed dietary MCS contributed to less body weight loss of lactating sows because dietary MCS may break down NSPs pigs cannot generally use into available sugars, resulting in improved utilization of nutrients to make more energy. In addition, previous study showed addition of NSP degrading enzymes in pig diets containing high NSP reduced negative effects of NSP and affected nutrient digestibility and performance of pigs positively [21,22].

Sows fed MCS had lower number of WBC on d $3(p<0.05)$ and TGF- $\beta 1$ on $\mathrm{d} 7(p<0.10)$ during lactation than those fed CON, but MCS did not modify concentration of TNF- $\alpha$, CRP, and cortisol of lactating sows compared with CON (Table 3). Sow farrowing is the stressful event that can negatively affect productive performance and increase inflammation by modulating immune system of lactating sows after farrowing [23,24]. It is important for lactating sows to recover the stress soon after farrowing for maintenance of their body condition and nursing their litter normally. The present study showed dietary MCS decreased WBC and TGF- $\beta 1$ within 7 days after farrowing. It may indicate dietary MCS contributes to attenuation of inflammation caused by the stress from farrowing, resulting in fast recovery of lactating sows from the stress. Previous study reported that dietary carbohydrases could change substrates for gut microbes, especially beneficial microbes, by degrading NSPs in pig diets and it could affect gut health and immunity of pigs positively and indirectly [25]. Moreover, another studies indicated that the substrates from NSPs degradation by dietary carbohydrases, such as short chain oligosaccharides, could modulate immunity of pigs like prebiotic effects directly [26-28].

Piglets from sows fed MCS had higher $(p<0.05)$ average weight gain and body weight at weaning day (Table 2), less $(p<$ $0.10)$ frequency of diarrhea (Table 2), lower $(p<0.05)$ number of $\mathrm{WBC}$ on $\mathrm{d} 3$ and $\mathrm{d} 7$ and TGF- $\beta 1$ and CRP on $\mathrm{d}$ during lactation (Table 4), and higher $(p<0.10) \operatorname{IgG}$ and IgM on $\mathrm{d} 7$ during lactation (Table 5) than those from sows fed CON. However, no differences were found on concentration of TNF- $\alpha$ and cortisol between CON and MCS (Table 4). The beneficial effects of dietary MCS on performance and immune responses of lactating sows mentioned above may save more energy for sows to make more milk and may make sows faster recovery and healthy. These potential benefits may make nursery piglets bigger and heathy by improving average body weight gain, reducing frequency of diar-

Table 3. Effects of multi-carbohydrases on number of WBC, serum TNF- $\alpha$, TGF- $\beta 1$, CRP and cortisol of lactating sows

\begin{tabular}{|c|c|c|c|c|}
\hline \multirow{2}{*}{ Item } & \multicolumn{2}{|c|}{ Treatments } & \multirow{2}{*}{ SEM } & \multirow{2}{*}{$p$-value } \\
\hline & CON & MCS & & \\
\hline \multicolumn{5}{|l|}{ Day 0} \\
\hline WBC $\left(\times 10^{3} / \mu \mathrm{L}\right)$ & 15.02 & 14.48 & 1.016 & 0.718 \\
\hline TNF- $\alpha(p g / m L)$ & 265.63 & 313.21 & 19.827 & 0.121 \\
\hline TGF- $\beta 1$ (pg/mL) & 719.73 & 742.90 & 74.003 & 0.829 \\
\hline CRP (ng/mL) & 260.77 & 195.50 & 31.604 & 0.175 \\
\hline Cortisol (ng/mL) & 2.51 & 2.58 & 0.206 & 0.821 \\
\hline \multicolumn{5}{|l|}{ Day 3} \\
\hline WBC $\left(\times 10^{3} / \mu \mathrm{L}\right)$ & 13.70 & 11.37 & 0.614 & $<0.05$ \\
\hline TNF- $\alpha(p g / m L)$ & 267.52 & 257.77 & 6.617 & 0.322 \\
\hline TGF- $\beta 1$ (pg/mL) & 785.20 & 704.56 & 69.273 & 0.430 \\
\hline $\mathrm{CRP}(\mathrm{ng} / \mathrm{mL})$ & 193.08 & 186.32 & 31.313 & 0.882 \\
\hline Cortisol (ng/mL) & 2.88 & 2.52 & 0.221 & 0.301 \\
\hline \multicolumn{5}{|l|}{ Day 7} \\
\hline WBC $\left(\times 10^{3} / \mu L\right)$ & 12.60 & 12.28 & 0.695 & 0.754 \\
\hline TNF- $\alpha(p g / m L)$ & 279.33 & 252.36 & 26.023 & 0.740 \\
\hline TGF- $\beta 1$ (pg/mL) & 951.14 & 730.61 & 83.832 & $<0.10$ \\
\hline $\mathrm{CRP}(\mathrm{ng} / \mathrm{mL})$ & 167.75 & 127.49 & 35.199 & 0.438 \\
\hline Cortisol (ng/mL) & 2.59 & 2.43 & 0.333 & 0.743 \\
\hline
\end{tabular}

Values are presents as the least squares mean of 6 replicates for lactating sows.

WBC, white blood cells; TNF- $\alpha$, tumor necrosis factor- $\alpha$; TGF- $\beta 1$, transforming growth factor- $\beta 1$; CRP, C-reactive protein; CON, control diet based on corn and soybean meal; MCS, multi-carbohydrase diet; SEM, standard error of means. 
Table 4. Effects of multi-carbohydrases on number of WBC, serum TNF- $\alpha$, TGF- $\beta 1$, CRP and cortisol of nursing piglets

\begin{tabular}{|c|c|c|c|c|}
\hline \multirow{2}{*}{ Item } & \multicolumn{2}{|c|}{ Treatments } & \multirow{2}{*}{ SEM } & \multirow{2}{*}{$p$-value } \\
\hline & CON & MCS & & \\
\hline \multicolumn{5}{|l|}{ Day 3} \\
\hline WBC $\left(\times 10^{3} / \mu \mathrm{L}\right)$ & 10.69 & 9.17 & 0.337 & $<0.01$ \\
\hline TNF- $\alpha(p g / m L)$ & 264.14 & 282.11 & 7.132 & 0.571 \\
\hline TGF- $\beta 1$ (pg/mL) & 742.15 & 723.24 & 79.028 & 0.869 \\
\hline CRP (ng/mL) & 50.81 & 64.95 & 6.820 & 0.173 \\
\hline Cortisol (ng/mL) & 2.10 & 2.10 & 0.066 & 0.999 \\
\hline \multicolumn{5}{|l|}{ Day 7} \\
\hline WBC $\left(\times 10^{3} / \mu \mathrm{L}\right)$ & 17.77 & 13.22 & 1.109 & $<0.01$ \\
\hline TNF- $\alpha$ (pg/mL) & 290.39 & 290.43 & 18.321 & 0.999 \\
\hline TGF- $\beta 1$ (pg/mL) & 869.89 & 757.52 & 33.774 & $<0.05$ \\
\hline $\mathrm{CRP}(\mathrm{ng} / \mathrm{mL})$ & 128.65 & 92.63 & 9.349 & $<0.05$ \\
\hline Cortisol (ng/mL) & 2.26 & 2.24 & 0.139 & 0.911 \\
\hline \multicolumn{5}{|l|}{ Day 28 (weaning day) } \\
\hline WBC $\left(\times 10^{3} / \mu \mathrm{L}\right)$ & 16.74 & 15.74 & 1.507 & 0.649 \\
\hline TNF- $\alpha(p g / m L)$ & 358.61 & 348.65 & 16.150 & 0.672 \\
\hline TGF- $\beta 1$ (pg/mL) & $1,058.97$ & $1,055.12$ & 135.405 & 0.984 \\
\hline CRP (ng/mL) & 110.16 & 78.47 & 20.732 & 0.305 \\
\hline Cortisol (ng/mL) & 4.24 & 4.09 & 0.306 & 0.735 \\
\hline
\end{tabular}

Values are presented as the least square mean of 6 replicates for nursing piglets.

WBC, white blood cells; TNF- $\alpha$, tumor necrosis factor- $\alpha$; TGF- $\beta 1$, transforming growth factor- $\beta 1$; CRP, C-reactive protein; CON, control diet based on corn and soybean meal; MCS, multi-carbohydrase diet; SEM, standard error of means.

Table 5. Effects of multi-carbohydrases on serum immunoglobulin G, M, and A of nursing piglets

\begin{tabular}{|c|c|c|c|c|}
\hline \multirow{2}{*}{ Item } & \multicolumn{2}{|c|}{ Treatments } & \multirow{2}{*}{ SEM } & \multirow{2}{*}{$p$-value } \\
\hline & CON & MCS & & \\
\hline \multicolumn{5}{|l|}{ Day 3} \\
\hline $\operatorname{lgG}(\mathrm{ng} / \mathrm{mL})$ & 58.62 & 51.75 & 7.261 & 0.519 \\
\hline $\operatorname{lgM}(\mathrm{ng} / \mathrm{mL})$ & 18.51 & 21.89 & 4.887 & 0.636 \\
\hline $\operatorname{lgA}(\mathrm{ng} / \mathrm{mL})$ & 11.95 & 5.55 & 38.948 & 0.914 \\
\hline \multicolumn{5}{|l|}{ Day 7} \\
\hline $\lg G(\mathrm{ng} / \mathrm{mL})$ & 247.04 & 278.37 & 10.493 & $<0.10$ \\
\hline $\operatorname{lgM}(\mathrm{ng} / \mathrm{mL})$ & 22.22 & 29.00 & 2.383 & $<0.10$ \\
\hline $\lg \mathrm{A}(\mathrm{ng} / \mathrm{mL})$ & 81.81 & 71.55 & 26.409 & 0.789 \\
\hline
\end{tabular}

Values are presented as the least square mean of 6 replicates for piglets.

CON, control diet based on corn and soybean meal; MCS, multi-carbohydrase diet; SEM, standard error of means; IgG, immunoglobulin G; IgM, immunoglobulin M; IgA, immunoglobulin A.

rhea, and attenuating immune responses.

\section{Conclusion}

In conclusion, addition of dietary MCS in the lactating sow diet based on corn and soybean meal improved productive performance and attenuated immune responses of lactating sows and their litters.

\section{Competing interests}

No potential conflict of interest relevant to this article was reported.

\section{Funding sources}

This work was supported by the National Research Foundation of Korea (NRF) grant funded by the Ministry of Science, Information and Communications Technology (ICT) and Future Planning (2016M3C1B5907057). 


\section{Acknowledgements}

Not applicable.

\section{Availability of data and material}

Upon reasonable request, the datasets of this study can be available from the corresponding author.

\section{Authors' contributions}

Conceptualization: Cho JY, Park IH, Song M.

Data curation: Lee JJ, Kang J, Park S, Seo D, Park IH.

Formal analysis: Lee JJ, Choi SH, Choe J.

Methodology: Lee JJ, Cho JH, Cho JY.

Software: Kim S, Park IH, Oh S.

Validation: Lee JJ, Choi SH, Cho JH, Kim HB, Song M.

Investigation: Lee JJ, Kyoung H, Song M.

Writing - original draft: Lee JJ, Song M.

Writing - review \& editing: Choi SH, Cho J, Kim HB, Song M

\section{Ethics approval and consent to participate}

The experimental protocol for this study was reviewed and approved by the Animal Care and Use Committee of Chungnam National University (Approval\# CNU-00611).

\section{ORCID}

Jeong Jae Lee

Seong Ho Choi

Jin $\mathrm{Ho}$ Cho

Joowon Kang

Soyun Kim

Sangwoo Park

Hyunjin Kyoung

Dongoh Seo

Jeehwan Choe

Jee-Yeon Cho

Il-Hun Park

Sangnam Oh

Hyeun Bum Kim

Minho Song

\section{References}

1. Kerr BJ, Shurson GC. Strategies to improve fiber utilization in swine. J Anim Sci Biotechnol. 2013;4:11-23.

2. Gutierrez NA, Serao NV, Patience JF. Effects of distillers' dried grains with solubles and soybean oil on dietary lipid, fiber, and amino acid digestibility in corn-based diets fed to growing pigs. J Anim Sci. 2016;94:1508-19.

3. Bach Knudsen KE. Carbohydrate and lignin contents of plant materials used in animal feeding. Anim Feed Sci Technol. 1997;67:319-38.

4. Hartman PA, Hays VW, Baker RO, Neagle LH, Catron DV. Digestive enzyme development in the young pig. J Anim Sci. 1961;20:114-23.

5. Lindemann MD, Cornelius SG, El Kandelgy SM, Moser RL, Pettigrew JE. Effect of age, weaning and diet on digestive enzyme levels in the piglet. J Anim Sci.1986;62:1298-307.

6. Huguet A, Savary G, Bobillier E, Lebreton Y, Le Huerou-Luron I. Effects of level of feed intake on pancreatic exocrine secretions during the early postweaning period in piglets. J Anim Sci. 2006;84:2965-72.

7. Adrio JL, Demain AL. Microbial enzymes: tools for biotechnological processes. Biomolecules. 2014;4:117-39.

8. Raveendran S, Parameswaran B, Beevi Ummalyma S, Abraham A, Mathew AK, Madhavan A, et al. Applications of microbial enzymes in food industry. Food Technol Biotechnol. 2018;56:16-30.

9. Choct M, Annison G. Anti-nutritive effect of wheat pentosans in broiler chickens: roles of viscosity and gut microflora. Br Poult Sci. 1992;33:821-34.

10. Annison G. Commercial enzyme supplementation of wheatbased diets raises ileal glycanase activities and improves apparent metabolisable energy, starch and pentosan digestibilities in broiler chickens. Anim Feed Sci Technol. 1992;38:105-21.

11. Salih ME, Classen HL, Campbell GL. Response of chickens fed on hull-less barley to dietary beta-glucanase at different ages. Anim Feed Sci Technol. 1991;33:139-49.

12. Tervila-Wilo A, Parkkonen T, Morgan A, Hopeakoski-Nurminen M, Poutanen $\mathrm{K}$, Heikkinen $\mathrm{P}$, et al. In vitro digestion of wheat microstructure with xylanase and cellulase from trichoderma reesei. J Cereal Sci. 1996;24:215-25.

13. Pedersen MB, Yu S, Arent S, Dalsgaard S, Knudsen KEB, Laerke HN. Xylanase increased the ileal digestibility of nonstarch polysaccharides and concentration of low molecular weight nondigestible carbohydrates in pigs fed high levels of wheat distillers dried grains with solubles. J Anim Sci. 2015;93:2885-93.

14. Zeng ZK, Li QY, Tian QY, Xu YT, Piao XS. The combination of carbohydrases and phytase to improve nutritional value and non-starch polysaccharides degradation for growing pigs fed diets with or without wheat bran. Anim Feed Sci Technol. 2018;235:138-46.

15. Tsai T, Dove CR, Cline PM, Owusu-Asiedu A, Walsh MC, Azain M. The effect of adding xylanase or beta-glucanase to diets with corn distillers dried grains with solubles (CDDGS) on growth performance and nutrient digestibility in nursery pigs. Livest Sci. 2017;197:46-52. 
16. Upadhaya SD, Lee SI, Kim IH. Effects of cellulase supplementation to corn soybean meal-based diet on the performance of sows and their piglets. Anim Sci J. 2016;87:904-10.

17. Song M, Baidoo SK, Shurson GC, Whitney MH, Johnston LJ, Gallaher DD. Dietary effects of distillers dried grains with solubles on performance and milk composition of lactating sows. J Anim Sci. 2010;88:3313-9.

18. Baidoo SK, Kil DY, Kim JN, Liu Y, Kim J, Kim K, et al. Productive performance of sows fed increasing levels of distillers dried grains with solubles (DDGS) across parities. Rev Colomb Cienc Pecu. 2014;27:171-7.

19. Kim J, Seo J, Kim W, Yun HM, Kim SC, Jang Y, et al. Effects of palm kernel expellers on productive performance, nutrient digestibility, and white blood cells of lactating sows. Asian-Australas J Anim Sci. 2015;28:1150-4.

20. Choe J, Kim S, Cho JH, Lee JJ, Park S, Kim B, et al. Effects of different gestation housing types on reproductive performance of sows. Anim Sci J. 2018;89:722-6.

21. Woyengo TA, Ige DV, Akinremi OO, Nyachoti CM. Performance and nutrient digestibility in growing pigs fed wheat dried distillers' grain with solubles-containing diets supplemented with phytase and multi-carbohydrase. Anim Sci J. 2016;87:570-7.

22. Zijlstra RT, Li S, Owusu-Asiedu A, Simmins PH, Patience JF. Effect of carbohydrase supplementation of wheat-and canola-meal-based diets on growth performance and nutrient digestibility in group-housed weaned pigs. Can J Anim Sci.
2004;84:689-95.

23. Song M, Liu Y, Lee JJ, Che TM, Soares-Almeida JA, Chun $\mathrm{JL}$, et al. Spray-dried plasma attenuates inflammation and improves pregnancy rate of mated female mice. J Anim Sci. 2015;93:298-305.

24. Liu Y, Choe J, Lee JJ, Kim J, Campbell JM, Polo J, et al. Spraydried plasma attenuates inflammation and lethargic behaviors of pregnant mice caused by lipopolysaccharide. PloS One. 2018;13:e203427.

25. Pluske JR, Pethick DW, Hopwood DE, Hampson DJ. Nutritional influences on some major enteric bacterial diseases of pig. Nutr Res Rev. 2002;15:333-71.

26. Kiarie E, Romero LF, Nyachoti CM. The role of added feed enzymes in promoting gut health in swine and poultry. Nutr Res Rev. 2013;26:71-88.

27. Van Craeyveld V, Swennen K, Dornez E, Van de Wiele T, Marzorati M, Verstraete W, et al. Structurally different wheat-derived arabinoxylooligosaccharides have different prebiotic and fermentation properties in rats. J Nutr. 2008;138:2348-55.

28. Pedersen MB, Yu S, Arent S, Dalsgaard S, Bach Knudsen $\mathrm{KE}$, Laerke HN. Xylanase increased the ileal digestibility of nonstarch polysaccharides and concentration of low molecular weight nondigestible carbohydrates in pigs fed high levels of wheat distillers dried grains with solubles. J Anim Sci. 2015;93:2885-93. 